Article

\title{
Determination of Salmonella spp., E. coli VTEC, Vibrio spp., and Norovirus GI-GII in Bivalve Molluscs Collected from Growing Natural Beds in Sardinia (Italy)
}

\author{
Marta Marceddu ${ }^{1}$, Sonia Lamon ${ }^{1}$, Simonetta G. Consolati ${ }^{1}$, Sara Ciulli ${ }^{2}$, Roberta Mazza $^{1}$, \\ Anna Mureddu ${ }^{1}$ and Domenico Meloni ${ }^{1, *}$ \\ 1 Dipartimento di Medicina Veterinaria, Università degli Studi di Sassari, Via Vienna 2, 07100 Sassari, Italy; \\ mmarceddu@uniss.it (M.M.); sonialamon@gmail.com (S.L.); sgconsolati@uniss.it (S.G.C.); \\ rmazza@uniss.it (R.M.); anna.mureddu@tin.it (A.M.) \\ 2 Dipartimento di Scienze Mediche Veterinarie, Alma Mater Studiorum, Università di Bologna, Via Tolara di \\ Sopra 50, 40064 Ozzano dell'Emilia, Italy; sara.ciulli@unibo.it \\ * Correspondence: dmeloni@uniss.it; Tel.: +39-079-229-570; Fax: +39-079-229-458
}

Received: 1 August 2017; Accepted: 4 October 2017; Published: 11 October 2017

\begin{abstract}
The aim of the present study was to evaluate the presence of Salmonella spp., verotoxigenic E. coli (VTEC), Vibrio spp., and Norovirus GI-GII in bivalve molluscs, cockles, and European grooved carpet shells (Cerastoderma spp. and Ruditapes decussatus) collected from a class B growing natural bed in Sardinia (Italy). All of the samples were analysed for Salmonella spp. detection according to European Commission Regulation (EC) 2285/2015. Detection and enumeration of Vibrio spp. were performed according to previously published methods. Presumptive identification of Vibrio spp. isolates was performed by means of conventional biochemical tests. E. coli VTEC was isolated following a direct multiplex polymerase chain reaction (PCR) screening test. Norovirus GI and GII were determined by reverse transcriptase-polymerase chain reaction (RT-PCR). No Salmonella spp. were detected. The prevalence of Vibrio spp. was $90 \%$, and the average contamination levels were $3.19 \pm 1.07$ and $2.84 \pm 0.31 \log _{10} \mathrm{cfu} / \mathrm{g}$ in cockles and European grooved carpet shells, respectively. The prevalence of E. coli VTEC was $6.6 \%$. All of the isolates showed a complete pathogenicity profile. The presence of Norovirus was highlighted in $25 \%$ of European grooved carpet shells samples. Results showed the typical microbiological profile of bivalve molluscs collected from backwaters and confirmed the capability of shellfish to accumulate E. coli VTEC, pathogenic vibrios, and Norovirus. The presence of such pathogens in shellfish is of major concern for the safety of consumers.
\end{abstract}

Keywords: shellfish; E. coli VTEC; Vibrio spp.; Norovirus

\section{Introduction}

Foodborne zoonoses associated with the consumption of bivalve molluscs are reported worldwide [1-4]. Shellfish contamination occurs because they are suspension feeders that selectively filter and concentrate small particles of phytoplankton, zooplankton, and the contaminant substances associated with them: bacteria of faecal origin and pathogens adapted to the marine environment, viruses, algal biotoxins, and chemicals [5-8]. Viruses and naturally occurring vibrios are the most often cited causative agents of disease and death related to shellfish consumption [1,5,9]. Although Salmonella spp. is considered one of the most common causes of human gastroenteritis [10], the risk of foodborne diseases associated with mollusc consumption is low compared to viruses and naturally occurring vibrios [11]. The incidence of foodborne outbreaks associated with the consumption of shellfish contaminated with Norovirus and pathogenic vibrios is increasing, although in many European 
countries production control plans are being implemented [7,12,13]. According to current European Legislation (Council Regulation (EC) 2285/2015), the evaluation of shellfish safety is based entirely on the use of E. coli as an indicator of faecal contamination. Historically, faecal indicator bacteria including total and faecal coliforms and enterococci have been used in many countries as a monitoring tool and for the prediction of the presence of bacterial, viral, and protozoan pathogens. These microorganisms are of faecal origin from higher mammals and birds, and their presence in water may indicate faecal pollution and possible association with enteric pathogens [8]. Several studies [14-16] have shown that faecal indicators provide an inadequate index of microbiological safety and are poorly predictive of the presence of microorganisms adapted to the aquatic environment (Vibrio spp.) and other pathogens detected in limited numbers (Noroviruses, E. coli O157). Norovirus (NoV) causes self-limiting infections characterised by gastrointestinal symptoms that have an average incubation time of $36 \mathrm{~h}$; it generally lasts for about $48 \mathrm{~h}$ and resolves spontaneously without complications. Although viral gastroenteritis has low mortality rates $(0.1 \%)$, the annual incidence recorded in some countries makes relevant economic and social costs and public health in general. However, the absence of epidemiologic episodes suggests that the number of reported cases represents an underestimation of the true incidence, especially in terms of medium or small forms that do not require recourse to hospitalisation [17]. Among pathogenic microorganisms adapted to the marine environment and involved in episodes of human infection, naturally occurring pathogenic vibrios, as V. parahaemolyticus, $V$. cholerae, and V. vulnificus are the most important [18]. The prevalence of such microorganisms in molluscs is variable and is strongly related to the heterogeneity of the microbiological methods, which differ mainly due to incubation temperatures $\left(20-25^{\circ} \mathrm{C}\right.$ or $\left.37^{\circ} \mathrm{C}\right)$. Several authors reported a prevalence of Vibrio spp. in seafood samples collected in Italy, ranging from $34 \%$ to $93 \%[9,19,20]$. Verotoxigenic E. coli (VTEC) is not commonly found in fishery products, but it has been documented that shellfish harvested in areas contaminated by landfill can carry VTEC and enterotoxigenic E. coli (ETEC) [8]. Generally, they are isolated from the gastrointestinal tract of ruminants, which are recognised as the main reservoirs [21]. A significant number of human infections due to E. coli are caused by serotype O157, mainly through the consumption of contaminated food, but also by contact with the environment and/or the use of water [22]. VTECs, predominantly O157, have been isolated in breeding environments from different sites such as soil, manure, sewage, drinking water, irrigation water, crops, and various equipment [8]. From agricultural environments, they can be transferred to watercourses, especially during periods of high rainfall, and subsequently spread to coastal areas [23]. Shellfish harvested in these areas can consequently concentrate the pathogen and thereby pose a risk to the health of consumers. In Italy, bivalve molluscs represent the most important aquaculture resource, representing over the half of total national production, mainly composed by Manila clams and Mediterranean mussels [22]. Nowadays, Italy is the leading European producer of Manila clams and the second in the world after China [24-26]. In Sardinia, the regional shellfish sector is well consolidated: the annual production accounts for $83 \%$ of the aquaculture species and rests almost exclusively on Mediterranean mussel [27]. Alongside aquaculture areas, cockles (Cerastoderma spp.) and European grooved carpet shells (Ruditapes decussatus) are native species typical of growing natural beds in several lagoons of remarkable naturalistic value, where artisanal fishing is currently practiced. These bivalve molluscs are harvested mainly for local consumption and are often consumed raw or lightly cooked. Recent literature on the occurrence of E. coli VTEC, Salmonella spp., Vibrio spp., and Norovirus in the Sardinian bivalve molluscs supply chain is limited. Therefore, the aim of the present study was to evaluate their presence in Cerastoderma spp. and Ruditapes decussatus collected from a class B growing natural bed. 


\section{Materials and Methods}

\subsection{Sampling}

The survey was conducted on samples $(n=40)$ from four batches of cockles $(n=20)$ and grooved carpet shells $(n=20)$ from class B growing natural bed present in the lagoons of the Oristano province (Sardinia, Italy). A batch is a quantity of live bivalve molluscs collected from the same production area and subsequently intended for delivery to an approved dispatch centre, purification centre, relaying area, or processing plant as appropriate. Five samples per batch were collected after the purification treatment. The purification centre was "recirculating": bivalve molluscs were placed in high density polyethylene (HDPE) tanks stacked on top of each other and supplied by a common seawater source in parallel. The flow of disinfected water by ultraviolet light (UV) was introduced into the tank by means of a spray bar onto the surface of the water. Before the disinfection of water, additional treatments including protein skimmers and biofilters were applied to recirculated seawater to reduce the concentrations of proteins and ammonia from shellfish.

\subsection{Microbiological Analysis}

All the samples were shipped, refrigerated, to the laboratories of the Dipartimento di Medicina Veterinaria, Università degli Studi (Sassari) in insulated boxes, and were submitted to microbiological analysis within $24 \mathrm{~h}$ of harvesting. Samples were processed for microbiological detection, enumeration, and graduated dilutions according to the ISO 6887-1: 2004 method.

\subsubsection{Detection of Salmonella spp.}

All the samples were analysed for Salmonella spp. detection according to the Official International Organisation for Standardisation (ISO) cultural methods, UNI EN 6579:2002. Briefly, $25 \mathrm{~g}$ of each sample were added to $225 \mathrm{~mL}$ of Buffered Peptone Water (BPW) and incubated at $37{ }^{\circ} \mathrm{C}$ for $18 \mathrm{~h}$ (Thermo Fisher Scientific, Waltham, MA, USA). Following incubation, $100 \mu \mathrm{L}$ of the BPW enrichment were inoculated in $10 \mathrm{~mL}$ of Rappaport-Vassiliadis soya enrichment broth (RVS) and incubated at $42{ }^{\circ} \mathrm{C}$ for $24 \mathrm{~h}$ while $100 \mu \mathrm{L}$ of the BPW enrichment were streaked over the surface of a Modified Semi-Solid Rappaport-Vassiliadis agar plate (MSRV) and incubated at $42{ }^{\circ} \mathrm{C}$ for $24 \mathrm{~h}$. Finally, $1 \mathrm{~mL}$ of the BPW enrichment was transferred to $10 \mathrm{~mL}$ of Muller-Kaufmann tetrathionate-novobiocin broth (MKTTn) amended with iodine and novobiocin. Following incubation, RVS, MKTTn, and MSRV were subcultured onto the surface of one Xylose-Lysine-Desoxycholate (XLD) agar plate to obtain well-isolated colonies, incubated at $37{ }^{\circ} \mathrm{C}$ for $24 \mathrm{~h}$. After incubation, XLD plates were examined for characteristic typical salmonella-like colonies with black centres and a light transparent zone of reddish colour.

\subsubsection{Detection of E. coli VTEC}

For the direct determination of E. coli VTEC, $10 \mathrm{~g}$ of each sample were subjected to selective enrichment in $90 \mathrm{~mL}$ of modified-Tryptone Soya Broth (m-TSB) containing novobiocin $(20 \mathrm{mg} / \mathrm{L})$ and incubated at $37^{\circ} \mathrm{C}$ for $18-20 \mathrm{~h}$. Subsequently, an aliquot was frozen at $-20{ }^{\circ} \mathrm{C}$ (Angelantoni Industrie Spa, Massa Martana, Italy) for immuno-magnetic separation (IMS) screening test by using the protocol for the E. coli O157, O26, O103, O111, and O145 Dynabeads capture (Dynal, Oslo, Norway), as described by the manufacturer. Another aliquot equal to $1 \mathrm{~mL}$ was used for DNA extraction using the Chelex 100 (BioRad, Hercules, CA, USA) resins. VTEC detection was carried out by a polymerase chain reaction (PCR) one-step method for the determination of st $x 1$ and st $x 2$ genes using the primer sets MK1/MK2 [28]. A negative control (NCTC 12900) and a positive control (ATCC 35150) were included at each PCR test. All PCR amplifications were performed by using a GeneAmp PCR System 9700 (Applied Biosystems, Foster City, CA, USA). All PCR-positive samples (VTEC presence) were subjected to qualitative determination of E. coli O157, O26, O103, O145, and O111 serogroups by IMS using Dynabeads anti-E. coli (Invitrogen, Carlsbad, CA, USA). Each Dynabeads-microorganism complex was 
streaked on CT-SMAC (MacConkey agar cefixime tellurite sorbitol, Thermo Fisher Scientific Oxoid Ltd., Basingstoke, UK) for the detection of serogroup O157, CT-RMAC (MacConkey agar cefixime tellurite rhamnose, Thermo Fisher Scientific Oxoid Ltd, Basingstoke, UK) for O26, and EHLY (Enterohemolysin agar, Thermo Fisher Scientific Oxoid Ltd, Basingstoke, UK) for serogroups O103, O111, and O145. All of the plates were incubated at $37^{\circ} \mathrm{C}$ for $24 \mathrm{~h}$. Isolates with typical morphological characteristics were subjected to biochemical identification by the $\mathrm{API}^{\circledR} 20 \mathrm{E}$ identification system (bioMérieux, Craponne, France). All of the isolated E. coli were subjected to a multiplex PCR for the detection of stx1, stx2, hlyA, and eae genes [29].

\subsubsection{Detection and Enumeration of Vibrio spp.}

Detection and enumeration of Vibrio spp. were carried out by plating $0.1 \mathrm{~g}$ of shellfish homogenate and its 10-fold dilutions over the surface of $3 \% \mathrm{NaCl}$ thiosulfate-citrate-bile salts-sucrose agar plates (TCBS, Thermo Fisher Scientific Oxoid Ltd, Basingstoke, UK). The plates were incubated at $20{ }^{\circ} \mathrm{C}$ for 3-5 days [30]. Presumptive identification of Vibrio spp. isolates was performed by means of conventional biochemical tests: five colonies from the plates of each medium were randomly selected and streaked on $3 \% \mathrm{NaCl}$ tryptone soya agar plates (TSA-s, Thermo Fisher Scientific Oxoid Ltd., Basingstoke, UK), and then incubated at $30{ }^{\circ} \mathrm{C}$ for $24 \mathrm{~h}$. Colonies on TSA-s were successively screened by oxidase and catalase tests, Gram staining, sugar fermentation, and sensitivity to vibriostatic agent O129. Presumptive biochemical identification was carried out by the API identification system (bioMérieux, Craponne, France).

\subsection{Virological Analysis}

From pooled cockles and European grooved carpet shells samples, stomach and digestive diverticula were isolated by dissection to obtain $5-10 \mathrm{~g}$ of tissue. Viral RNA was extracted according to previously described methods [31]. NoV detection was carried out by a RT-PCR one-step method using the previously described primer sets JV13I and JV12Y [32]. Subsequently, NoV GI and GII were determined by two specific semi-nested RT-PCR [33,34].

\section{Results}

\subsection{Microbiological Analysis}

\subsubsection{Detection of Salmonella spp.}

Salmonella spp. was not detected in $25 \mathrm{~g}$ of samples of cockles and European grooved carpet shells.

\subsubsection{Detection of E. coli VTEC}

The direct PCR method used for the preliminary screening of VTECs showed a total prevalence of $6.6 \%$. One sample of cockles and one of European grooved carpet shells exhibited a positive result during the same sampling session. However, conventional PCR is generally less sensitive than real-time PCR, so this could be an underestimation of frequency. Altogether, 10 E. coli strains were isolated: $n$. 2 O157; $n .2$ O26; $n$. 2 O103, $n .2$ O145, and $n .2$ O11. All of the isolates showed a complete pathogenicity profile $(s t x 1+$, st $x 2+$, eae,$+ h l y \mathrm{~A}+)$. The prevalence of naturally occurring vibrios was $90 \%$, and the average contamination levels (mean \pm standard deviation (s.d.)) were $3.19 \pm 1.07$ and $2.84 \pm 0.31 \log _{10} \mathrm{cfu} / \mathrm{g}$ in cockles and European grooved carpet shells, respectively (Table 1). 
Table 1. Enumeration (mean \pm s.d.) of Vibrio spp. ( $\left.\log _{10} \mathrm{cfu} / \mathrm{g}\right)$ in Cerastoderma spp. and Ruditapes decussatus after purification.

\begin{tabular}{cccccc}
\hline \multirow{2}{*}{ Vibrio spp. } & $\mathbf{5}$ & Batch * \\
\cline { 2 - 6 } & $\mathbf{1}$ & $\mathbf{2}$ & $\mathbf{3}$ & $\mathbf{4}$ & Mean \\
\hline Cerastoderma spp. & $3.76 \pm 1.45$ & $2.74 \pm 0.37$ & $2.86 \pm 0.25$ & $3.40 \pm 0.15$ & $3.19 \pm 1.07$ \\
\hline Ruditapes decussatus & $2.68 \pm 0.22$ & $2.94 \pm 0.36$ & $2.83 \pm 0.45$ & $2.84 \pm 0.1$ & $2.84 \pm 0.31$ \\
\hline
\end{tabular}

\subsubsection{Detection and Enumeration of Vibrio spp.}

The use of TCBS agar $\mathrm{NaCl} 3 \%$ with incubation at $20^{\circ} \mathrm{C}$ allowed for the recovery of an abundance of Vibrio spp. in all of the samples. However, when used for direct plating, TCBS may underestimate the contamination levels [30]. Altogether, 36 Vibrio spp. isolates were presumptively identified by biochemical tests using the API 20 NE identification system (bioMérieux, Craponne, France). The prevalent species were $V$. vulnificus (98\%) and V. alginolyticus ( $2 \%)$.

\subsection{Virological Analysis}

The presence of NoV was highlighted in $25 \%$ of the samples (European grooved carpet shells). Regarding the prevalence of the two genogroups, the results (25\% GII-positive and 10\% GI-positive) confirmed the higher circulation of GII with respect to GI in shellfish $[10,35,36]$. On the contrary, only two samples presented simultaneous contamination with both genogroups.

\section{Discussion}

The results of the present study showed the typical microbiological profile of bivalve molluscs collected from backwaters and confirmed the capability of shellfish to accumulate E. coli VTEC, Norovirus, and pathogenic vibrios. Salmonella spp. was not detected, and this result was not surprising; recent studies have shown that its presence is strongly related to the bivalve species considered, the classification areas in which molluscs were collected, and the sampling occasion [37]. Shellfish harvested from coastal areas near agricultural environments are at high risk of pollution of agro-zootechnical origin and may be contaminated by E. coli VTEC transferred from contaminated animals to watercourses [21]. However, the low prevalence of VTEC in shellfish could be related to the low number of these pathogens in the coastal environment, to the presence of competitive bacterial flora, and to the reduced in vitro vitality of these microorganisms in respect to the marine environment [38]. The direct determination of E. coli by PCR allowed us to detect the presence/absence of VTEC directly in the food matrices. However, some difficulties in isolating strains from selective media highlights the need to further optimise the operational protocols. Some problems related to the factors that may interfere with the vitality and survival capacity of the strains should be resolved. The presence of NoV in shellfish (25\%) was not generally related to the presence of faecal bacteria. Moreover, their presence in polluted waters is very scarce due to the competitive action exerted by these bacteria [39]. A previous study carried out in several Italian regions showed NoV contamination in $51.5 \%$ of samples. Interestingly, the prevalence of NoV in samples collected in Sardinia was 62.1\% [35]. The recovery of NoV GI and GII posed an important health significance, in relation to the ability of such viruses to withstand the environment for longer periods in presence of favorable conditions. As previously reported $[3,40,41]$, the purification treatment, utilised worldwide to purge bivalve molluscs from faecal contaminants, was unsatisfactory with respect to seawater autochthonous vibrios. These results might be related to Vibrio spp. release dynamics in depuration [13,42]: all microbial species related to the aquatic habitat accumulate in the intestines of mussels where they can multiply, thus making the depuration systems ineffective [43,44]. V. vulnificus was the prevalent Vibrio spp. species: the presence of such pathogens in Sardinian bivalve molluscs is of major concern for the 
safety of consumers. In 2000-2001, two deaths caused by fulminant sepsis attributed to V. vulnificus were reported in the same production area. In both cases, subjects with severe chronic liver diseases manipulated and/or consumed contaminated bivalve molluscs a few days before death [45].

\section{Conclusions}

This survey is a practical contribution to the acquisition of data on the safety of bivalve molluscs (Ruditapes decussatus and Cerastoderma spp.) collected from class B growing natural beds in Sardinia (Italy). The presence of E. coli VTEC, pathogenic vibrios, and NoV in shellfish collected from natural environments, where artisanal fishing is currently practiced and these molluscs are consumed raw or lightly cooked, pose a significant risk to the health of consumers. Currently, in Regulation (EC) $2073 / 2005$ on the microbiological criteria applicable to foodstuffs, food safety criteria related to the presence of E. coli VTEC, pathogenic vibrios, and NoV in shellfish are not present.

Author Contributions: Marta Marceddu, Sonia Lamon, Simonetta G. Consolati, Sara Ciulli, Roberta Mazza, and Anna Mureddu collected the test data and interpreted the results. Domenico Meloni designed the study and drafted the manuscript.

Conflicts of Interest: The authors declare no conflict of interest.

\section{References}

1. Croci, L.; Serratore, P.; Cozzi, L.; Stacchini, A.; Milandri, S.; Suffredini, E.; Toti, L. Detection of Vibrionaceae in mussels and in their seawater growing area. Appl. Microbiol. 2001, 32, 57-61. [CrossRef]

2. Lozano-León, A.; Torres, J.; Osorio, C.R.; Martinez-Urtaza, J. Identification of tdh-positive Vibrio parahaemolyticus from an outbreak associated with raw oyster consumption in Spain. FEMS Microbiol. Lett. 2003, 226, 281-284. [CrossRef]

3. Serratore, P.; Ciulli, S.; Piano, A.; Cariani, A. Criticism of the purification process of bivalve shellfish. Literature review and our industrial research experiences. In Shellfish, Human Consumption Health Implication and Conservation Concerns; Hay, R.M., Ed.; Nova Publishers: New York, NY, USA, 2014; pp. 1-50.

4. Leoni, F.; Chierichetti, S.; Santarelli, S.; Talevi, G.; Masini, L.; Bartolini, C.; Rocchegiani, E.; Naceur Haouet, M.; Ottaviani, D. Occurrence of Arcobacter spp. and correlation with the bacterial indicator of faecal contamination Escherichia coli in bivalve molluscs from the Central Adriatic, Italy. Int. J. Food Microbiol. 2017, 245, 6-12. [CrossRef] [PubMed]

5. Battisti, A.; De Vita, R.; Castellano, S. Aspetti sanitari nel controllo microbiologico dei molluschi bivalvi. Industrie Alimentari 2016, 464, 1267-1269.

6. Dunphy, B.J.; Hall, J.A.; Jeffs, A.G.; Wells, R.M.G. Selective particle feeding by the Chilean oyster, Ostrea chilensis; Implications for nursery culture and broodstock conditioning. Aquaculture 2006, 261, 594-602. [CrossRef]

7. Corrain, C.; Arcangeli, G.; Fasolato, L.; Manfrin, A.; Rossetti, E.; Piazzi, E.; Mioni, R.; Pavoni, E.; Losio, N.; Sanavio, G.; et al. Influenze climatico-ambientali sulla presenza di virus enterici in molluschi bivalvi. Industrie Alimentari 2007, 46, 277-283.

8. Avery, L.M.; Williams, A.P.; Killham, K.; Jones, D.L. Survival of Escherichia coli O157:H7 in waters from lakes, rivers, puddles and animal drinking troughs. Sci. Total Environ. 2008, 389, 378-385. [CrossRef] [PubMed]

9. Parisi, A. Qualità igienica e presenza di vibrioni in ostriche, vongole e modiole. Ind. Aliment. 2004, 43, $28-32$.

10. European Food Safety Authority; European Centre for Disease Prevention and Control (EFSA and ECDC). The European Union summary report on trends and sources of zoonoses, zoonotic agents and food-borne outbreaks in 2015. EFSA J. 2016, 14, 4634.

11. Iwamoto, M.; Ayers, T.; Mahon, B.E.; Swerdlow, D.L. Epidemiology of seafood-associated infections in the United States. Clin. Microbiol. Rev. 2010, 23, 399-410. [CrossRef] [PubMed]

12. Comelli, H.L.; Rimstad, E.; Larsen, S.; Myrmel, M. Detection of norovirus genotype I.3b and II.4 in bioaccumulated blue mussels using different virus recovery methods. Int. J. Food Microbiol. 2008, 127, 53-59. [CrossRef] [PubMed] 
13. Bosch, A.; Pintó, R.M.; Le Guyader, F.S. Viral contaminants of molluscan shellfish: Detection and characterization. In Shellfish Safety and Quality; Shumway, S.E., Rodrick, G.E., Eds.; CRC Press Woodhead, Publishing Limited: Cambridge, UK, 2009; pp. 83-98.

14. Savichtcheva, O.; Okabe, S. Alternative indicators of fecal pollution: Relations with pathogens and conventional indicators, current methodologies for direct pathogen monitoring and future application perspectives. Water Res. 2006, 40, 2463-2476. [CrossRef] [PubMed]

15. Suffredini, E.; Mioni, R.; Mazzette, R.; Bordin, P.; Serratore, P.; Fois, F.; Piano, A.; Cozzi, L.; Croci, L. Detection and quantification of Vibrio parahaemolyticus in shellfish from Italian production areas. Int. J. Food Microbiol. 2014, 184, 14-20. [CrossRef] [PubMed]

16. Passalacqua, P.L.; Zavatta, E.; Bignami, G.; Serraino, A.; Serratore, P. Occurrence of Vibrio parahaemolyticus, Vibrio cholerae and Vibrio vulnificus in the clam Ruditapes philippinarum (Adams \& Reeve, 1850) from Emilia Romagna and Sardinia, Italy. Ital. J. Food Saf. 2016, 5, 41-46.

17. Food and Agriculture Organization of the United Nations. Bivalve Depuration: Fundamental and Practical Aspects; FAO Fisheries Technical Paper 511; Food and Agriculture Organization of the United Nations: Rome, Italy, 2008; ISBN 978-92-5-106006-3.

18. Caburlotto, G.; Lleo, M.M.; Gennari, M.; Balboa, S.; Romalde, J.L. The use of multiple typing methods allows a more accurate molecular characterization of Vibrio parahaemolyticus strains isolated from the Italian Adriatic Sea. FEMS Microbiol. Ecol. 2011, 77, 611-622. [CrossRef] [PubMed]

19. Serracca, L.; Gallo, F.; Magone, L.; Preparo, M.; Ercolini, C.; Orlandi, M. Caratterizzazione biochimica e tossicologica di Vibrio patogeni in prodotti ittici. Ind. Aliment. 2007, 46, 881-886.

20. Carraro, V.; Sanna, C.; Brandas, V.; Sanna, A.; Pinna, A.; Coroneo, V. Hygiene and health risks associated with the consumption of edible lamellibranch molluscs. Int. J. Food Microbiol. 2015, 201, 52-57. [CrossRef] [PubMed]

21. Caprioli, A.; Morabito, S.; Brugere, H.; Oswald, E. Enterohaemorrhagic Escherichia coli: Emerging issues on virulence and modes of transmission. Vet. Res. 2005, 36, 289-311. [CrossRef] [PubMed]

22. Chalmers, R.M.; Aird, H.; Bolton, F.J. Waterborne Escherichia coli O157. J. Appl. Microbiol. 2000, 88, 124S-132S. [CrossRef]

23. Williams, A.P.; Gordon, H.; Jones, D.L.; Strachan, N.J.C.; Avery, L.M.; Killham, K. Leaching of bioluminescent Escherichia coli O157:H7 from sheep and cattle faeces during simulated rainstorm events. J. Appl. Microbiol. 2008, 105, 1452-1460. [CrossRef] [PubMed]

24. Meloni, D.; Mureddu, A.; Pisanu, M.; Sferlazzo, G.; Serra, S.; Tempesta, A.; Piras, F.; Virgilio, S.; Mazzette, R. Valutazione dell'efficacia dei sistemi di depurazione nei confronti di E. coli, Salmonella spp. e Vibrio spp. in mitili allevati nel golfo di Olbia. Il Pesce 2010, 5, 165-172.

25. Bille, L.; Ceolin, C.; Dalla Pozza, M.; Toson, M.; Trolese, M.; Arcangeli, G. Risultati del piano di monitoraggio per il controllo delle patologie dei molluschi nel periodo 2007-2012. In Proceedings of the 2nd National Congress of SIRAM, Cesenatico, Italy, 29 Novembre 2013.

26. Sicuro, B.; Tarantola, M.; Valle, E. Italian aquaculture and the diffusion of alien species: Costs and benefits. Aquac. Res. 2016, 47, 3718-3728. [CrossRef]

27. Sardegna Agricoltura/Laore 2009. Il Comparto dell'Acquacoltura in Sardegna Alla Luce dei Risultati dell'Indagine Conoscitiva. Available online: http:/ / www.sardegnaagricoltura.it/assistenzatecnica/laore (accessed on 1 August 2017).

28. Karch, H.; Meyer, T. Single primer pair for amplifying segments of distinct Shiga-like-toxin genes by Polymerase Chain-Reaction. J. Clin. Microbiol. 1989, 27, 2751-2757. [PubMed]

29. Paton, J.C.; Paton, A.W. Pathogenesis and diagnosis of Shiga toxin-producing Escherichia coli infections. J. Clin. Microbiol. 1998, 11, 450-479.

30. Serratore, P.; Piano, A.; Piraccini, S.; Trentini, M.; Zavatta, E.; Grodzki, M.; Valeri, M.L. Survey of V. cholerae, $V$. vulnificus and $V$. parahaemolyticus, in bivalve molluscs of the Adriatic sea and proposal of an analytical protocol. Ital. J. Food Sci. 2009, 1, 33-38. [CrossRef]

31. Boom, R.; Sol, C.J.; Salimans, M.M.; Jansen, C.L.; Wertheim-van Dillen, P.M.; van der Noordaa, J. Rapid and simple method for purification of nucleic acids. J. Clin. Microbiol. 1990, 28, 495-503. [PubMed]

32. Vinjè, J.; Koopmans, M.P.G. Molecular detection and epidemiology of small round structured viruses in outbreaks of gastroenteritis in the Netherlands. J. Infect. Dis. 1996, 174, 610-615. [CrossRef] [PubMed] 
33. Green, J.; Henshilwood, K.; Gallimore, C.I.; Brown, D.W.G.; Lees, D.N. A nested reverse transcriptase PCR assay for detection of small round structured viruses in environmentally contaminated molluscan shellfish. Appl. Environ. Microbiol. 1998, 64, 858-863. [PubMed]

34. Boxman, I.L.A.; Tilburg, J.J.H.C.; te Loeke, N.A.J.M.; Vennema Jonker, K.; de Boer, E.; Koopmans, M. Detection of noroviruses in shellfish in the Netherlands. Int. J. Food Microbiol. 2006, 108, 391-396. [CrossRef] [PubMed]

35. Suffredini, E.; Lanni, L.; Arcangeli, G.; Pepe, T.; Mazzette, R.; Ciccaglioni, G.; Croci, L. Qualitative and quantitative assessment of viral contamination in bivalve molluscs harvested in Italy. Int. J. Food Microbiol. 2014, 184, 21-26. [CrossRef] [PubMed]

36. Pavoni, E.; Consoli, M.; Suffredini, E.; Arcangeli, G.; Serracca, L.; Battistini, R.; Rossini, I.; Croci, L.; Losio, M.N. Noroviruses in seafood: A 9-year monitoring in Italy. Foodborne Pathog. Dis. 2013, 10, 533-539. [CrossRef] [PubMed]

37. Rubini, S.; Galletti, G.; D’Incau, M.; Govoni, G.; Boschetti, L.; Berardelli, C.; Barbieri, S.; Merialdi, G.; Formaglio, A.; Guidi, E.; et al. Occurrence of Salmonella enterica subsp. enterica in bivalve molluscs and associations with Escherichia coli in molluscs and faecal coliforms in seawater. Food Control 2018, 84, 429-435. [CrossRef]

38. Rodriguez-Manzano, J.; Hundesa, A.; Calgua, B.; Carratala, A.; Maluquer de Motes, C.; Rusinol, M.; Moresco, V.; Ramos, A.P.; Martinez-Marca, F.; Calvo, M.; et al. Adenovirus and Norovirus contaminants in commercially distributed shellfish. Food Environ. Virol. 2014, 6, 31-41. [CrossRef] [PubMed]

39. Gourmelon, M.; Montet, M.P.; Lozach, S.; Le Mennec, C.; Pommepuy, M.; Beutin, L.; Vernozy-Rozand, C. First isolation of Shiga toxin 1d producing Escherichia coli variant strains in shellfish from coastal areas in France. J. Appl. Microbiol. 2006, 100, 85-97. [CrossRef] [PubMed]

40. Suffredini, E.; Corrain, C.; Arcangeli, G.; Fasolato, L.; Manfrin, A.; Rossetti, E.; Biazzi, E.; Mioni, R.; Pavoni, E.; Losio, M.N.; et al. Occurrence of enteric viruses in shellfish and relation to climatic environmental factors. Lett. Appl. Microbiol. 2008, 47, 467-474. [CrossRef] [PubMed]

41. Normanno, G.; Parisi, A.; Addante, N.; Quaglia, N.C.; Dambrosio, A.; Montagna, C.; Chiocco, D. Vibrio parahaemolyticus, Vibrio vulnificus and microorganisms of fecal origin in mussels (Mytilus galloprovincialis) sold in the Puglia region (Italy). Int. J. Food Microbiol. 2006, 106, 219-222. [CrossRef] [PubMed]

42. Leoni, F.; Talevi, G.; Masini, L.; Ottaviani, D.; Rocchegiani, E. Trh (tdh-/trh+) gene analysis of clinical, environmental and food isolates of Vibrio parahaemolyticus as a tool for investigating pathogenicity. Int. J. Food Microbiol. 2016, 225, 43-53. [CrossRef] [PubMed]

43. Aagesen, A.M.; Phuvasate, S.; Su, Y.C.; Hase, C.C. Persistence of Vibrio parahaemolyticus in the Pacific oyster, Crassostrea gigas, is a multifactorial process involving pili and flagella but not type III secretion systems or phase variation. Appl. Environ. Microbiol. 2013, 79, 3303-3305. [CrossRef] [PubMed]

44. Desemarchelier, P.M. Vibrio. In Enciclopedya of Food Microbiology; Robinson, R., Batt, C., Patel, P., Eds.; Academy Press: Cambridge, MA, USA, 2000; pp. 2237-2242.

45. Madeddu, S.; Scarano, C.; Dessì, M.P.; Palomba, P.; Crasta, M. Monitoraggio per la ricerca di Vibrio vulnificus in acque e prodotti della pesca nelle lagune della provincia di Cagliari. In Proceedings of the Atti del XIV Convegno Nazionale AIVI, Santuario di Vicoforte, Cuneo, Italy, 4-6 Giugno 2004; pp. 105-110.

(C) 2017 by the authors. Licensee MDPI, Basel, Switzerland. This article is an open access article distributed under the terms and conditions of the Creative Commons Attribution (CC BY) license (http:// creativecommons.org/licenses/by/4.0/). 